\title{
Cancers related to exposure to arsenic at a copper smelter
}

\author{
Philip E Enterline, Richard Day, Gary M Marsh
}

\begin{abstract}
Objective-This is an update of an earlier study on the relation between exposure to arsenic in air and deaths from respiratory cancer. The purpose was to verify earlier findings of a supralinear dose response relation and to examine relations with other cancers, particularly those reported in studies on drinking water.

Methods-An earlier study of 2802 men who worked at a copper smelter for a year or more during the period 1940-64 and who were followed up for deaths during the period 1941-76 was updated until 1986. Estimates of exposure for the period 1977-1984 were added.

Results and conclusions-The additional follow up confirms the earlier finding that at low doses the increments in death rates for respiratory cancer for a given increment in dose are greater than at high doses. The additional follow up also shows significant increases in cancer of the large intestine and bone, and SMRs $>150$ for cancer of the buccal cavity and pharynx, rectal cancer, and kidney cancer. There was a positive relation between exposure to arsenic in air and kidney and bone cancer, but none for the other cancers, except respiratory.
\end{abstract}

(Occup Environ Med 1995;52:28-32)

Keywords: arsenic; cancer; dose-response

We (PE, GM) previously reported on the mortality experience of 2802 men who were exposed to arsenic at a copper smelter at Tacoma, WA after a year or more of employment during the period 1940-64..$^{3}$ These reports showed an excess in deaths from respiratory cancer during the period 1941-76 with the excess related to cumulative airborne exposure to arsenic. In the most recent report, the respiratory cancer dose-response curve at lower exposures was much steeper than at higher exposures so that the dose-response curve was supralinear (concave downward). This was true for the relative as well as the absolute response, and for follow up that started at entry into the study, or follow up that started at the end of exposure. ${ }^{3}$ Thus, in the population we studied, the increments in respiratory cancer per unit dose were greater at low exposures than at high.

This is a report on the results of an addi- tional 10 years of follow up, until 1986. The purpose is to verify our previous findings and to explore an additional question, and that is whether inhaled arsenic is related to internal cancers as well as to respiratory cancer.

The copper smelter where workers in this study were exposed to arsenic started operations in 1913 and at one time was the largest in the United States, producing about $10 \%$ of the refined copper in the entire country. For many years it was the source of all of the arsenic commercially produced in the United States. Further information about this smelter is contained in an earlier paper. ${ }^{2}$

\section{Methods}

For the entire cohort of 2802 men who worked for a year or more during the period 1940-64 it was possible to determine vital status at the end of 1986 for $98.5 \%$. An additional 522 deaths were identified, which increased the total from 1061 in the last report to 1583 . Of 1583 known deaths, death certificates were obtained for 1530 or $96.6 \%$. The additional 522 deaths were traced through the United States Social Security Administration, the United States National Death Index, and by personal phone contacts. Death certificates were obtained from state Health Departments and coded by a nosologist to the underlying cause of death according to the revision of international classification of causes of death in effect at the time of death. For malignant neoplasms expected numbers of deaths were based upon the mortality of the population of the State of Washington. ${ }^{4}$ These are available for the entire follow up period 1941-86 for malignant neoplasms but only from 1960 for other causes of death. Thus, for this report follow up for non-malignant disease only starts in 1960 whereas follow up for malignant disease starts in 1941 .

In the calculation of expected deaths only mortality of white men was used as all the 2802 workers in the study were men and nearly all were white. Expected deaths were also calculated with death rates for Pierce County, the county where the smelter is located. ${ }^{4}$ Results were about the same as when Washington state rates were used. Because of larger numbers of deaths and more stable rates only Washington state rates are used in this report. Excesses and deficits in mortality are expressed as a standardised mortality ratio (SMR). This is the ratio of the observed to the expected number of deaths multiplied by 100 . 
Expected deaths are age-time specific death rates of white men for the state of Washington multiplied by person-years lived by the cohort in five year age-time intervals. The SMRs were calculated with the computer program OCMAP. ${ }^{5}$

Exposure to arsenic was estimated from departmental measurements of arsenic in air contained in company annual reports that started in 1938, and measurements of urinary arsenic identified by department and worker started in 1948 . We combined these data to allow an analysis of the relation between the concentrations of arsenic in air and various cancers.

Measurements of arsenic in air were mostly confined to departments in which arsenic was thought to be a problem. Measurements of urinary arsenic, on the other hand, were offered to all workers, and they represent all departments of the smelter. The conversion of data of urinary arsenic to air arsenic was made by the identification of departments and years for which data from both air and urinary arsenic were available and by the determination of the mathematical relation between the two. Although a total of 34 pairs of data were available, six pairs were deleted, one pair because the value of arsenic in air was based on only one sample and the other five pairs because notations in the annual reports indicated that the measurements of arsenic in air were not representative of normal working conditions. The remaining 28 pairs of data represented 11 of the 33 departments at the smelter.

Average concentrations of arsenic in air were weighted to reflect as closely as possible actual exposures of workers. Before 1971, data of arsenic in air came from spot samples and tape samples. As far as possible these were weighted for hours per shift at the sam- ple location, numbers of men at that location per shift, and frequency of operation (for samples that reflected exposure from a particular operation). Starting in 1971, data for arsenic in air were based on readings from personal samples. These seem to be representative of personal exposure for particular departments.

From these data an exposure matrix of arsenic in air was developed by department and year from 1938 up to the time the smelter closed in 1984. Combined with job histories for each worker cumulative exposure was calculated and expressed as $\mu \mathrm{g} / \mathrm{m}^{3} / \mathrm{y}$. For years before 1938 the exposure data for 1938 were used. Additional details on the method used in estimations of exposure are contained in an earlier report. ${ }^{3}$

\section{RESULTS FOR CANCER}

Table 1 shows the mortality experienced for selected malignant neoplasms in total and by time since first exposure. Overall, there were significant excesses for all malignant neoplasms taken together, cancer of the large intestine, cancer of the respiratory system, and bone cancer. When there were $<20$ years since first exposure the only significant excess is for respiratory cancer. For $\geqslant 20$ years since first exposure SMRs are generally higher but those that are significant are the same as for the total cohort.

As well as the cancers that were significantly in excess in table 1 there are three sites for which there were 10 or more deaths and for which the SMRs were $>150$ but were not significant. For cancer of the buccal cavity and pharynx the SMR was 168.7 based on 12 deaths. For rectal cancer the SMR was $176 \cdot 0$ based on 15 deaths, and for kidney cancer there were 11 deaths and the SMR was $163 \cdot 5$. Ten of the 11 deaths from kidney cancer occurred $\geqslant 20$ years after first exposure.

Table 1 Observed $(O)$ and expected $(E)$ deaths and SMRs for selected cancers by years since first exposure, Tacoma copper smelter

\begin{tabular}{|c|c|c|c|c|c|c|c|c|c|}
\hline \multirow[b]{2}{*}{ Cancer site } & \multicolumn{3}{|l|}{ Total } & \multicolumn{3}{|c|}{ Exposure $<20 y$} & \multicolumn{3}{|c|}{ Exposure $\geqslant 20 y$} \\
\hline & $O$ & $E$ & $S M R$ & $O$ & $E$ & $S M R$ & $O$ & $E$ & $S M R$ \\
\hline $\begin{array}{l}\text { All malignant neoplasms: } \\
\text { Buccal cavity and pharynx } \\
\text { Digestive organs and peritoneum: } \\
\text { Oesophagus } \\
\text { Stomach } \\
\text { Large intestine } \\
\text { Rectum } \\
\text { Biliary passages and liver } \\
\text { Pancreas } \\
\text { All other digestive } \\
\text { Respiratory system: } \\
\text { Larynx } \\
\text { Bronchus, trachea, lung } \\
\text { All other respiratory } \\
\text { Breast } \\
\text { Prostate } \\
\text { Testes and other male genital organs } \\
\text { Kidney } \\
\text { Bladder and other urinary organs } \\
\text { Malignant melanoma of skin } \\
\text { Eye } \\
\text { Central nervous system } \\
\text { Thyroid and other endocrine glands } \\
\text { Bone } \\
\text { All lymphatic, haematopoietic: } \\
\text { Lymphosarcoma and reticulosaroma } \\
\text { Hodgkin's disease } \\
\text { Leukemia and aleukemia } \\
\text { All other lymphopoietic tissue } \\
\text { All other malignant neoplasms }\end{array}$ & $\begin{array}{r}395 \\
12 \\
95 \\
7 \\
18 \\
38 \\
15 \\
1 \\
14 \\
2 \\
188 \\
3 \\
182 \\
3 \\
0 \\
28 \\
1 \\
11 \\
8 \\
1 \\
1 \\
5 \\
1 \\
5 \\
24 \\
3 \\
2 \\
9 \\
10 \\
15\end{array}$ & \begin{tabular}{r|}
$276 \cdot 06$ \\
$7 \cdot 12$ \\
$79 \cdot 08$ \\
$6 \cdot 08$ \\
$16 \cdot 43$ \\
$23 \cdot 48$ \\
$8 \cdot 52$ \\
$4 \cdot 72$ \\
$16 \cdot 26$ \\
$3 \cdot 59$ \\
$89 \cdot 65$ \\
$3 \cdot 17$ \\
$85 \cdot 03$ \\
1.46 \\
$0 \cdot 46$ \\
$25 \cdot 62$ \\
1.31 \\
$6 \cdot 73$ \\
$9 \cdot 61$ \\
2.56 \\
0.28 \\
$8 \cdot 15$ \\
$1 \cdot 00$ \\
$1 \cdot 10$ \\
$27 \cdot 21$ \\
5.36 \\
2.91 \\
$11 \cdot 28$ \\
7.66 \\
$16 \cdot 20$
\end{tabular} & 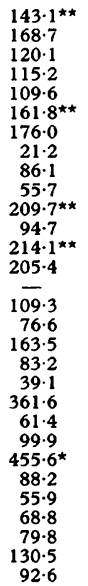 & $\begin{array}{r}43 \\
2 \\
11 \\
0 \\
2 \\
2 \\
4 \\
0 \\
2 \\
1 \\
17 \\
0 \\
17 \\
0 \\
0 \\
2 \\
1 \\
1 \\
1 \\
0 \\
0 \\
0 \\
0 \\
0 \\
7 \\
0 \\
2 \\
2 \\
3 \\
1\end{array}$ & $\begin{array}{r}36 \cdot 10 \\
1 \cdot 14 \\
10 \cdot 94 \\
0.64 \\
2 \cdot 79 \\
2 \cdot 61 \\
1 \cdot 33 \\
0 \cdot 58 \\
2 \cdot 19 \\
0 \cdot 80 \\
9 \cdot 66 \\
0 \cdot 42 \\
9 \cdot 04 \\
0 \cdot 20 \\
0 \cdot 10 \\
1 \cdot 23 \\
0 \cdot 70 \\
1 \cdot 04 \\
0 \cdot 94 \\
0 \cdot 55 \\
0 \cdot 04 \\
1.98 \\
0 \cdot 24 \\
0 \cdot 28 \\
5 \cdot 16 \\
1 \cdot 21 \\
1 \cdot 20 \\
2 \cdot 04 \\
0 \cdot 70 \\
2 \cdot 11\end{array}$ & $\begin{array}{c}119 \cdot 1 \\
175 \cdot 8 \\
100 \cdot 6 \\
\overline{71} \cdot 8 \\
76 \cdot 8 \\
299 \cdot 9 \\
\overline{91} \cdot 5 \\
125 \cdot 0 \\
176 \cdot 0^{\star} \\
\overline{ } \\
188 \cdot 1^{\star} \\
- \\
163 \cdot 2 \\
143 \cdot 2 \\
95 \cdot 9 \\
106.7 \\
- \\
- \\
- \\
- \\
135.5 \\
166.4 \\
97 \cdot 8 \\
426 \cdot 8 \\
47.5\end{array}$ & $\begin{array}{r}352 \\
10 \\
84 \\
7 \\
16 \\
36 \\
11 \\
1 \\
12 \\
1 \\
171 \\
3 \\
165 \\
3 \\
0 \\
26 \\
0 \\
10 \\
7 \\
1 \\
1 \\
5 \\
1 \\
5 \\
17 \\
3 \\
0 \\
7 \\
7 \\
14\end{array}$ & $\begin{array}{r}239.95 \\
5.98 \\
68.14 \\
5.44 \\
13.64 \\
20.87 \\
7.19 \\
4.13 \\
14.07 \\
2.79 \\
79.99 \\
2.75 \\
75.99 \\
1.26 \\
0.36 \\
24.39 \\
0.61 \\
5.69 \\
8.67 \\
2.00 \\
0.23 \\
6.16 \\
0.76 \\
0.82 \\
22.05 \\
4.15 \\
1.70 \\
9.24 \\
6.96 \\
14.09\end{array}$ & $\begin{array}{c}146 \cdot 7^{\star \star} \\
167 \cdot 3 \\
123 \cdot 3 \\
128 \cdot 8 \\
117 \cdot 3 \\
172 \cdot 5^{\star \star} \\
153 \cdot 0 \\
24 \cdot 2 \\
85 \cdot 3 \\
35 \cdot 8 \\
213 \cdot 8^{\star \star} \\
109 \cdot 2 \\
217 \cdot 1^{\star \star} \\
238 \cdot 1 \\
106 \cdot 6 \\
175 \cdot 9 \\
170 \cdot 7 \\
49 \cdot 9 \\
428 \cdot 1 \\
81 \cdot 1 \\
131 \cdot 7 \\
610 \cdot 2^{\star \star} \\
77 \cdot 1 \\
72 \cdot 3 \\
75 \cdot 8 \\
100 \cdot 6 \\
99 \cdot 3\end{array}$ \\
\hline
\end{tabular}

${ }^{\star} \mathrm{P}<0.05 ;{ }^{\star \star} \mathrm{P}<0.01$. 
Table 2 Observed (O) and expected (E) deaths and SMRS for respiratory cancer by cumulative airborne arsenic and date of hire, Tacoma copper smelter

\begin{tabular}{|c|c|c|c|c|c|c|c|c|c|c|c|}
\hline \multirow{2}{*}{$\begin{array}{l}\text { Cumulative } \\
\text { exposure } \\
\left(\mu g / m^{\prime} y\right)\end{array}$} & \multirow{2}{*}{$\begin{array}{l}\text { Mean } \\
\text { exposure } \\
\text { (total cohor) }\end{array}$} & \multirow{2}{*}{$\begin{array}{l}\text { Person- } \\
\text { years }\end{array}$} & \multicolumn{3}{|c|}{ Total cohort } & \multicolumn{3}{|c|}{ Hired $<1940$} & \multicolumn{3}{|c|}{ Hired $\geqslant 1940$} \\
\hline & & & $O$ & $E$ & $S M R$ & $O$ & $E$ & $S M R$ & $O$ & $E$ & $S M R$ \\
\hline $\begin{array}{l}<750 \\
750- \\
2000- \\
4000- \\
8000- \\
20000- \\
45000\end{array}$ & $\begin{array}{l}405 \\
1305 \\
2925 \\
5708 \\
12334 \\
28336 \\
58957\end{array}$ & $\begin{array}{r}20445 \\
19111 \\
15804 \\
13747 \\
10934 \\
4114 \\
761\end{array}$ & $\begin{array}{r}22 \\
30 \\
36 \\
36 \\
39 \\
20 \\
5\end{array}$ & $\begin{array}{r}14 \cdot 29 \\
17 \cdot 10 \\
17 \cdot 17 \\
17 \cdot 00 \\
15 \cdot 48 \\
7 \cdot 04 \\
1 \cdot 58\end{array}$ & $\begin{array}{l}154 \cdot 0 \\
175 \cdot 5^{\star \star} \\
209 \cdot 7^{\star \star} \\
211 \cdot 7^{\star \star} \\
252 \cdot 0^{\star \star} \\
284 \cdot 0^{\star \star} \\
315 \cdot 7^{\star}\end{array}$ & $\begin{array}{r}2 \\
5 \\
22 \\
15 \\
28 \\
14 \\
5\end{array}$ & \begin{tabular}{r|}
3.08 \\
7.33 \\
8.93 \\
10.01 \\
10.98 \\
5.56 \\
1.48
\end{tabular} & $\begin{array}{c}65 \cdot 0 \\
68 \cdot 2 \\
246 \cdot 2^{\star \star} \\
149 \cdot 9^{\star \star} \\
255 \cdot 1^{\star \star} \\
251 \cdot 7^{\star \star} \\
338 \cdot 7^{\star}\end{array}$ & $\begin{array}{r}20 \\
25 \\
14 \\
21 \\
11 \\
6 \\
0\end{array}$ & $\begin{array}{r}11 \cdot 21 \\
9 \cdot 77 \\
8 \cdot 23 \\
7 \cdot 00 \\
4 \cdot 50 \\
1 \cdot 48 \\
0 \cdot 11\end{array}$ & $\begin{array}{l}178 \cdot 4^{\star} \\
256 \cdot 0^{\star \star} \\
170 \cdot 1 \\
300 \cdot 2^{\star \star} \\
244 \cdot 4^{\star} \\
405 \cdot 5^{\star \star} \\
-\end{array}$ \\
\hline
\end{tabular}

$\star P<0.05 ; \star \star P<0.01$.

Table 2 shows the relation between cumulative exposure to arsenic in air expressed as $\mu \mathrm{g} / \mathrm{m}^{3} / \mathrm{y}$ and cancer of the respiratory system for the entire cohort, for the cohort hired before 1940, and for the cohort hired in 1940 or later. The reason for this stratification is that for the cohort hired before 1940 only the person-years accumulated from 1941 were followed up for deaths, whereas for the cohort hired in 1940 and later all the person-years, to the end of the follow up period, were assessed. The stratification to some extent also separated workers before 1940 with relatively high exposure and with poor respiratory protection from workers with lower exposure, but with better exposure data and perhaps better respiratory protection.

Table 2 shows the data that are plotted with dose on a log scale in fig 1 . For the entire cohort the SMRs are almost a straight line. When the cohort was separated into those hired before 1940 , and 1940 or later the plots are more irregular, but trends are roughly similar to that for the entire cohort. Some of the differences are probably related to the smaller numbers upon which the divided cohort is based and it does not seem that the combination of the two cohorts is inappropriate for determination of the shape of the doseresponse relation between arsenic and respiratory cancer.

When absolute rather than relative increments in mortality are calculated the plots for the entire cohort are similar to those in fig 1 . If, for the entire cohort, dose is plotted on an arithmetic scale rather than on a logarithmic scale the dose-response curve is concave downward-like the relation previously reported for the years $1941-76 .{ }^{3}$ For the entire cohort, the linear correlation between $\log$ dose and SMRs in fig 1 is highly significant $(P<0.001)$. The fitted regression equation between dose and SMRs is a power function:

SMR $=100+10 \cdot 5$ (cumulative exposure) $\$ 279$

Compared with the regression equation reported for the years 1941-76 this new equation, which includes 10 years additional follow up, has slightly more curvature than the old equation and strengthens the evidence for relatively large increments in respiratory cancer at low exposures. Figure 2 compares the dose-response curve for the period 1941-86 with the curve previously reported for the period 1941-76. Note that the horizontal scale is arithmetic. The power function for follow up to 1986 is an almost perfect fit.

Table 3 shows the relation of the other cancer sites already discussed with cumulative exposure to arsenic in air. Here cancer of the large intestine has been combined with colon cancer as these are sometimes confused diagnostically and, moreover, the aetiology of these cancers is likely to be the same. There does not seem to be any relation between cumulative exposure to arsenic in air and either colorectal or buccal cancer. There is a weak relation for kidney and bone cancers.

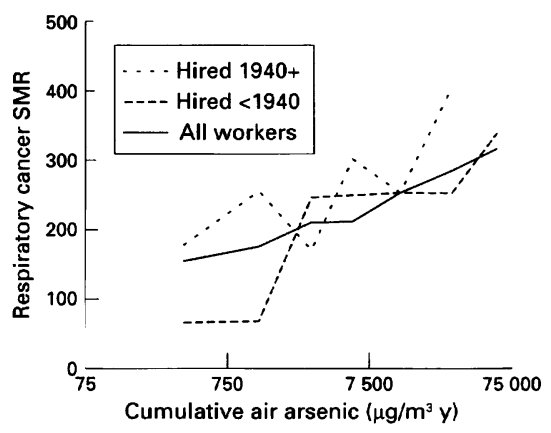

Figure 1 The SMRs for respiratory cancer for cumulative airborme arsenic and date of hire. Copper smelter workers from Tacoma 1941-86. Data are plotted at the means of exposure intervals.

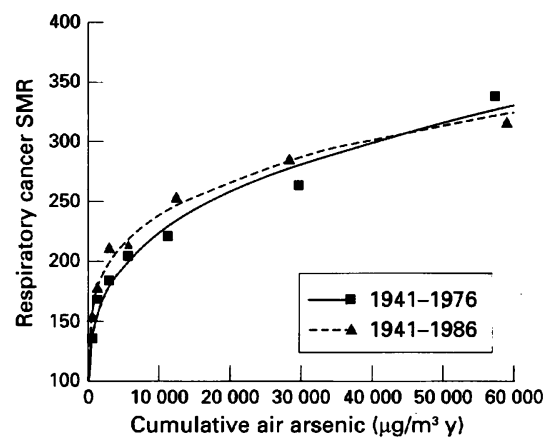

Figure 2 The SMRs for respiratory cancer for cumulative airborne arsenic. Copper smelter workers from Tacoma 1941-76 and 1941-86. Data are plotted at the means of exposure intervals. Fitted lines are from corresponding power functions. 
Table 3 Observed $(O)$ and expected $(E)$ deaths and SMRS for selected cancers by cumulative exposure to airborme arsenic, Tacoma copper smelter

\begin{tabular}{|c|c|c|c|c|c|c|c|c|c|c|c|c|}
\hline \multirow{2}{*}{$\begin{array}{l}\text { Cumulative } \\
\text { exposure } \\
\left(\mu g / m^{3} y\right)\end{array}$} & \multicolumn{3}{|c|}{ Buccal } & \multicolumn{3}{|c|}{ Colorectal } & \multicolumn{3}{|c|}{ Kidney } & \multicolumn{3}{|c|}{ Bone } \\
\hline & $O$ & $E$ & $S M R$ & $O$ & $E$ & $S M R$ & $O$ & $E$ & $S M R$ & $O$ & $E$ & $S M R$ \\
\hline $\begin{array}{l}<750 \\
750- \\
2000- \\
4000- \\
8000- \\
20000- \\
45000-\end{array}$ & $\begin{array}{l}2 \\
2 \\
5 \\
3 \\
0 \\
0 \\
0\end{array}$ & $\begin{array}{l}1.07 \\
1.29 \\
1.37 \\
1.36 \\
1.30 \\
0.60 \\
0.13\end{array}$ & $\begin{array}{l}186 \cdot 7 \\
154 \cdot 8 \\
366 \cdot 2 \\
220 \cdot 3 \\
= \\
-\end{array}$ & $\begin{array}{r}5 \\
9 \\
12 \\
13 \\
10 \\
3 \\
1\end{array}$ & $\begin{array}{l}\mathbf{4} \cdot 23 \\
5 \cdot 30 \\
6 \cdot 02 \\
6 \cdot 34 \\
6 \cdot 32 \\
3 \cdot 07 \\
0 \cdot 70\end{array}$ & $\begin{array}{r}118.2 \\
169.8 \\
199.3 \\
205.0 \\
158.2 \\
97.7 \\
137.0\end{array}$ & $\begin{array}{l}0 \\
2 \\
1 \\
3 \\
2 \\
3 \\
0\end{array}$ & $\begin{array}{l}1.03 \\
1.23 \\
1.38 \\
1.29 \\
1.21 \\
0.56 \\
0.13\end{array}$ & $\begin{array}{l}\overline{162 \cdot 5} \\
78 \cdot 2 \\
232 \cdot 2 \\
165 \cdot 6 \\
538 \cdot 0^{\star} \\
--\end{array}$ & $\begin{array}{l}0 \\
0 \\
0 \\
1 \\
4 \\
0 \\
0\end{array}$ & $\begin{array}{l}0 \cdot 17 \\
0 \cdot 19 \\
0 \cdot 21 \\
0 \cdot 21 \\
0 \cdot 20 \\
0 \cdot 09 \\
0 \cdot 02\end{array}$ & $\begin{array}{l}- \\
- \\
470 \cdot 0 \\
1969 \cdot 8^{\star \star} \\
- \\
-\end{array}$ \\
\hline
\end{tabular}

$\star \mathrm{P}<0.05 ; \star \star \mathrm{P}<0.01$

RESULTS FOR OTHER CAUSES OF DEATH

Data on non-malignant diseases (table 1) were calculated for the period 1960-86. As already noted, expected deaths are based on the mortality in the state of Washington for the years 1960-86. There were a total of 1234 deaths for all causes during these years and the SMR was $118.8 \quad(\mathrm{P}<0.01)$. When selected causes were examined there were significant excesses for ischemic heart disease $(P<0.01)$ and for non-malignant respiratory disease, excluding bronchitis, emphysema, and asthma $(P<0.05)$. There were 428 deaths from ischemic heart disease and the SMR was $115 \cdot 0$. This was weakly related to cumulative exposure to arsenic. For the exposure categories shown on table 2, the SMRs and number of deaths were: $107 \cdot 6(55), 103 \cdot 2$ (67), 106.6 (74), 121.6 (87), 127.5 (91; $\mathrm{P}<$ $0.05), 131.7(46)$, and $89.5(8)$. For nonmalignant respiratory disease there were 41 deaths and a slight negative relation, with the less exposed workers having the highest SMR.

\section{COMPARISONS WITH OTHER STUDIES}

An association between exposure to arsenic in air and respiratory or lung cancer has been reported for several other occupationally exposed populations. ${ }^{6-15}$ Evidence for the kind of dose-response relation reported here for respiratory cancer has recently been summarised and commented upon by HertzPicciotto and Smith with data from one of our

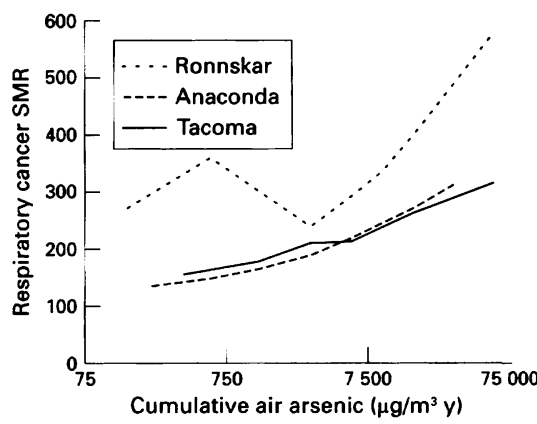

Figure 3 The SMRs for respiratory cancer (Anaconda and Tacoma) and lung cancer (Ronnskar) for cumulative airborne arsenic. To facilitate presentation the upper three exposure categories for Ronnskar have been combined. Tacoma plots are as for fig 1. Anaconda and Ronnskar are plotted at the midpoint of exposure intervals except for upper intervals 30000 and 57000 , which were used based in part on the exposure distributions in the data from Tacoma. earlier reports. ${ }^{316}$ There are data from two copper smelters that seem to be comparable with our study. Figure 3 shows the doseresponse relation reported for a United States copper smelter at Anaconda, MT and for a copper smelter at Ronnskar, Sweden along with data from our study. ${ }^{14}{ }^{15}$ As in fig 1 , the horizontal scale is logarithmic. Only data reported by one of the investigators of the Anaconda smelter are shown. ${ }^{14}$ Other data for the Anaconda smelter have been reported by Lee-Feldstein but the shape of the doseresponse curves is similar to that in fig $2 . .^{13}$ There are also exposure data for the Anaconda smelter that have been adjusted downward, and thus higher SMRs for each exposure category can be calculated. ${ }^{14}$ This raises the dose-response curve, particularly at higher doses where it is nearly midway between the Tacoma and the Ronnskar data.

The dose-response curves for the two copper smelters located in the United States are similar. For the Swedish smelter the response in terms of lung cancer is higher at each level of exposure than for the United States smelters. The authors of the report on the Swedish smelter thought that some of the excess in lung cancer might be due to an excess in smoking when compared with the general population. A more recent report shows that smoking probably was not a factor in the high death rate from lung cancer. ${ }^{17}$

\section{Discussion}

Studies of cancer related to arsenic in drinking water indicate increases in cancer of the lung, bladder, kidney, skin, liver, and colon..$^{1819}$ Gibb and Chen have compared studies of sites with excessive cancer between arsenic inhalation (like our study) and arsenic ingestion, and have concluded that there is some agreement. ${ }^{20}$ Our study lends some support for a relation between exposure to arsenic in air and kidney cancer but little support for the other cancers except lung cancer.

One important difference between studies of occupationally and environmentally exposed cohorts is that for most of the environmentally exposed cohorts exposure starts at birth, whereas for the occupationally exposed cohorts exposure of interest starts much later in life. In our study the mean age at first exposure was about 30 years. If the latent period for some cancers caused by ingestion is very long these might be missed in a study of occupationally exposed 
populations. We looked for skin cancers in the smelter population of Tacoma and found no excess. ${ }^{21}$ These are rarely fatal and could only be found at work, not very long after the onset of exposure. Skin cancer related to arsenic in drinking water does not usually appear until after the age of 30 and the incidence rises rapidly with age. ${ }^{22}$ Thus, the latent period for skin cancer and perhaps other cancers related to ingested arsenic could be very long, so perhaps this is the reason these were not seen in the smelter worker population of Tacoma. It may also be that, as noted by Bates et al, in comparison with populations exposed to arsenic in drinking water the exposure of our population, and perhaps other populations exposed to arsenic in air is relatively low. ${ }^{19}$

One cancer with an apparently short latent period in this study is respiratory cancer. As table 1 shows, a significant excess (SMR = 203.3 ) occurred in $<20$ years. The SMR remained around 200 in successive 10 year periods and was $151.9 \geqslant 50$ years since first exposure. We are not aware of published studies of other workers from copper smelters that report increments in respiratory or lung cancer by time from first exposure. Ott et al reported no deaths from respiratory cancer in a population occupationally exposed to insecticides containing arsenic $<15$ years from first exposure $(0.4$ expected), but did report excesses for the subsequent time since first exposure categories. "In a study by us (PE, GM) of workers at a copper smelter at Salt Lake City, UT where there was exposure to arsenic the SMR for respiratory cancer $<20$ years since first exposure was 170.0 (11 deaths) and $\geqslant 20$ years 107.8 (39 deaths). ${ }^{1223}$ Perhaps a short latent period is somehow related to the way exposure occurs in the lung as inhaled arsenic seems to be retained in the lung for long periods. ${ }^{24}$ On the other hand, perhaps the lung has a particular susceptibility. One curious finding in studies of arsenic in drinking water is a dose related excess in mortality from lung cancer-an excess surpassed only by an excess in urinary cancer. ${ }^{19}$ We are not aware of any other ingested substance that may cause lung cancer.

The dose-response relation between airborne arsenic and respiratory cancer found in this study is unusual. As noted in our earlier report, this could be because air measurements are not good measures of biological dose. ${ }^{3}$ The relation is not likely to be due to confounding, but this needs further study. Smoking can be an important confounder in respiratory cancer and data on the histories of the study population for smoking are being collected. These will be modelled along with other covariates in a future publication.

The excess we found in bone cancer has not, to our knowledge, been reported in other studies. As arsenic is stored in the bone, however, this may be an important finding. ${ }^{25} 26$ Of the five deaths coded by our nosologist to bone cancer, two were mandible, one hip, one spine, and one ribs. For the spine and ribs information on the death certificate indicated that these may not have been the primary sites. If we had recoded these, however, it would have invalidated our comparison with the external control population.

This research was supported in part by the US Environmental Protection Agency. (Agreement No CR811173.)

1 Enterline PE, Marsh GM. Mortality study of copper smelter workers. Am f Ind Med 1980;1:251-9.

2 Enterline PE, Marsh GM. Cancer among workers exposed to arsenic and other substances in a copper smelrer. $A m^{\prime}$ Epidemiol 1982;116:895-911.

3 Enterline PE, Henderson VL, Marsh GM. Exposure to arsenic and respiratory cancer-a reanalysis. $\mathrm{Am} f$ Epidemiol 1987;125:929-38.

4 Marsh GM, Ehland J, Sefcik S. Mortality and population data system (MPDS). Pittsburgh: University of Pittsburgh, Department of Biostatistics, Technical Report, 1987.

5 Marsh GM, Preininger ME. A user-oriented occupational cohort mortality analysis program. American Statistician 1980;34:245.

6 Lee AM, Fraumeni JF Jr. Arsenic and respiratory cancer in man: an occupational study. I Nat Cancer Inst 1969; 42:1045-52.

7 Rencher AC, Carter MW, McKee DW. A retrospective epidemiological study of mortality at a large western copper smelter. $\mathcal{f}$ Occup Med 1977;19:754-8.

8 Tokudome S, Kuratsune $M$. A cohort study on mortality from cancer and other causes among workers at a metal refinery. Int $f$ Cancer 1976;17:310-7.

9 Sandstrom AIM, Wall SGI, Taube A. Cancer incidence and mortality among Swedish smelter workers. $\mathrm{Br} f$ Ind Med 1989;46:82-9.

10 Mabuchi K, Lilienfeld AM, Snell LM. Lung cancer among pesticide workers exposed to inorganic arsenicals. Arch Environ Health 1979;23:312-20.

11 Ott MG, Holder BB, Gordon HI. Respiratory cancer and occupational exposure to arsenicals. Arch Environ Healt 1974;29:250-5.

12 Enterline PE, Marsh GM, Esmen NA, Henderson VI Callahan CM, Paik $M$. Some effects of cigarette smoking, arsenic, and $\mathrm{SO}_{2}$ on mortality among US copper smelter workers. 7 Occup Med 1987;29:831-8.

13 Lee-Feldstein A. Cumulative exposure to arsenic and its relationship to respiratory cancer among copper smelter relationship to respiratory cancer among copf
employees. F Occup Med 1986;28:286-302.

14 Higgins I, Welch K, Oh MS, Kryston KL, Burchfiel CM Wilkinson NM. Arsenic exposure and respiratory cancer. Wilkinson NM. Arsenic exposure and respiratory cancer. University of Michigan, 1986 .

15 Jarup L, Pershagen G, Wall S. Cumulative arsenic exposure and lung cancer in smelter workers: a dose-respons study. Am f Ind Med 1989;15:31-41.

16 Hertz-Picciotto I, Smith AH. Observation on the doseresponse curve for arsenic exposure and lung cancer. Scand $\mathcal{f}$ Work Environ Health 1993;19:217-26.

17 Jarup L, Pershagen G. Arsenic exposure, smoking and lung cancer in smelter workers-a case-control study. Am $₹$ Epidemiol 1991;134:545-51.

18 Chen CJ, Chiang YC, Lin TM, Wen HY. Malignant neoplasms among residents of a Blackfoot disease-endemic area in Taiwan. Cancer Res 1985;45:5895-9.

19 Bates MN, Smith AH, Hopenhayn RC. Arsenic ingestion and internal cancers: a review. Am f Epidemiol 1992, and internal

$20 \mathrm{Gibb} \mathrm{H}$, Chen C. Is inhaled arsenic carcinogenic for sites other than the lung? In: Mohr U, Bates DV, Dungworth DL, Lee PN, McClellan RO, Roe FJC, eds. Assessment of inhalation hazards-integration and extrapolation using diverse data. Berlin: Springer-Verlag, 1989.

21 Andelman JB, Barnett $M$. Feasibility study to resolve questions on the relationship of arsenic in drinking water to skin cancer. Pittsburgh: Center for Environmental Epidemiology, University of Pittsburgh, 1984 (Technical Report 84-8.)

22 US Environmental Protection Agency. Special report on ingested inorganic arsenic. Washington: US EPA 1988. (EPA-625/3-87/013.)

23 Enterline PE, Marsh GM, Esmen N, Henderson V, Ricci E. Mortality among copper and zinc smelter workers in the United States. Final report to the Smelter Environmental Research Association. Pittsburgh, PA: University of Rittsburg, 1986.

24 Gerhardson Brune D, Nordberg GF, Wester PO. Multi-elemental assay of tissues of deceased smelter workers and controls. Sci Total Environ 1988;74:97-110.

25 Kadowski K. Studies on the arsenic contents in organ tissues of the normal Japanese. Osaka City Med f 1960 9:2083-8

26 Saady J, Blanke RV, Poklis A. Estimation of the body burden of arsenic in a child fatally poisoned by arsenite weed killer. F Anal Toxicol 1989;13:310-2. 